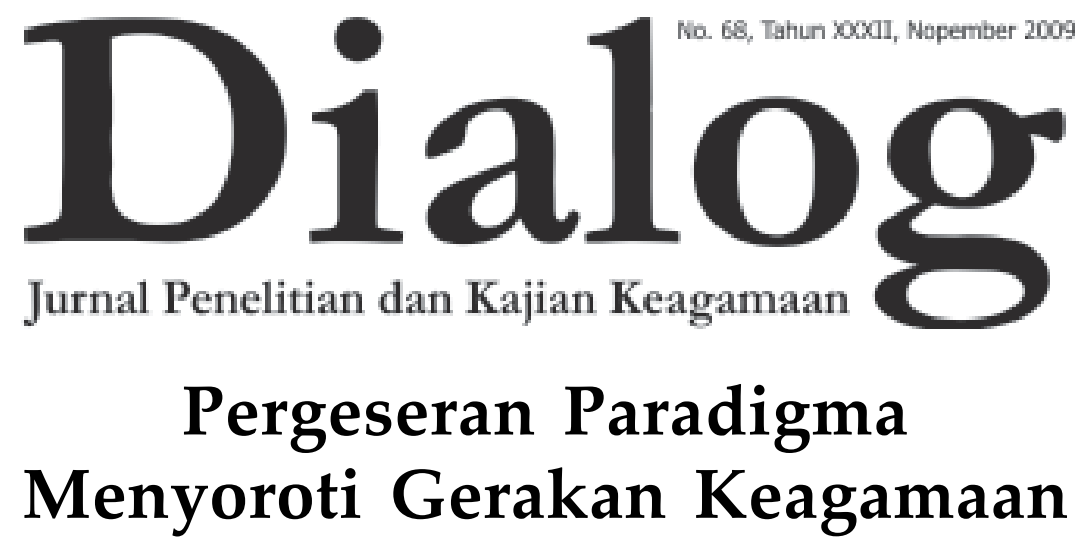




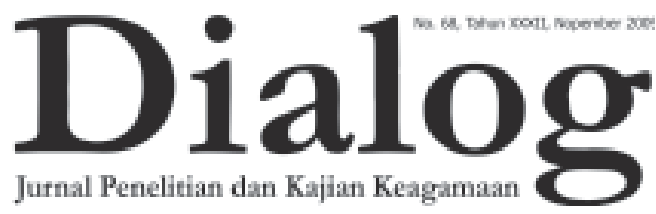

Pemi mpin Umum:

Prof. Dr. H. M. Atho Mudzhar, MA

Redaktur Ahli:

Prof. Dr. H. Nasaruddin Umar, MA

Prof. Dr. H. Komarudin Hidayat, MA

Pemimpin Redaksi / Penanggung J awab

Drs. H. Syamsuddin

Wakil Pemi mpin Redaksi

H. Fanani Suprianto, SH., MM

Sekretaris Redaksi

M. Rosyid Fauzi, S.Si.

Dewan Redaksı

Prof. Dr. H. Abdurrahman Mas'ud Drs. Amin Haedari

Prof. Dr. H. Maidir Harun

Drs. H. Mohammad Shohib, MA

Drs. H. Asmu'i, SH, MM

Chamdi Pamudji, SH., MM

Redaktur Eksekutif

M. Nasir, S.Th.I.

Redaktur Pelaksana

Moh. Rosyid Fauzi, S.Si

M. Nasir, S.Th.I

M. Adlin Sila, M.A

Abbas Jauhari, M.Ag

Administrasi

Drs. Dedy Curipno

Sutidjah

Desriyanti Nasution, S.IPI

Drs. H. Sahlani

Alamat Redaksi

Gedung Bayt Alquran Museum Istiqlal Komplek Taman Mini Indonesia Indah

Telp. (021) 87791444-87794982

Website:

www. balitbangdiklat.depag.go.id

Email:

info@depag.web.id

\section{Pergeseran Paradigma Menyoroti Gerakan Keagamaan}

Fenomena munculnya berbagai aliran keagamaan di Indonesia beberapa tahun terakhir menunjukan kecenderungan positif dalam kebebasan beragama. Namun sayangnya kebebasan menampilkan ekspresi keberagamaan tersebut kerapkali melampaui dari apa yang semestinya. Hal tersebut dapat kita lihat dengan munculnya gerakan keagamaan yang mengusung berbagai macam ajaran, ritual keagamaan yang aneh bahkan cenderung mengancam serta menodai kesucian aqidah, ibadah, ritual, dan pendirian mayoritas ummat yang sudah mapan. Sejak tahun 1989, setidaknya telah ada beberapa aliran keagamaan diberikan label haram oleh MUI (Majelis Ulama Indonesia), diantara aliran yang dianggap menyesatkan itu antara lain: Islam Jama'ah, Ahmadiyah, Ingkar Sunnah, Qur'an Suci, Sholat Dua Bahasa, Lia Eden dan al-Qiyadah al-Islamiyah.

Fenomena ini ditenggarai oleh sebagian pihak sebagai akibat dari kegagalan dakwah. Para da'i dianggap tidak mampu mentransformasikan nilainilai ajaran Islam secara kaffah 
(komprehensif) kepada ummat, dakwah selama ini sering bersifat eksklusif, menghakimi dan memprovokasi. Aktifitas dakwah hanya menampilkan Islam dari aspek langit atau 'ubudiyah (habluminallah) bukan aspek bumi dimana kehidupan sosial (habluminannas) bergulir, sehingga wajar berbagai permasalahan sosial yang dialami ummat tidak tersentuh. Fakta ini menyebabkan ummat mencari solusi lain atas permasalahan sosial yang mereka alami dengan cara "selingkuh" yaitu menganut sekte atau aliran baru dalam sebuah agama yang menawarkan solusi instan, namun cenderung "menyesatkan".

Para da'i, tokoh masyarakat, maupun para pemegang kebijakan ke depan harus mampu merubah paradigma yang selama ini salah dan telah mengkristal di kalangan ummat. Mereka diharapkan tidak berperan sebagai juru dakwah, juru vonis, juru putus, yang hanya menyampaikan pesan bil lisan di atas mimbar saja, tapi lebih dari itu, merek dituntut menjadi -meminjam istilah Clifford Geertz- cultural broker (makelar budaya), bahkan menjadi intermediary forces (kekuatan perantara) bagi permasalahan sosial ummat dalam istilah Hiroko Horikoshi.

Dalam kajian Jurnal Dialog Edisi ini mencoba mengulas tentang Pergeseran Paradigma Menyoroti Gerakan Keagamaan yang kerapkali menghadirkan tematema aktual di tengah-tengah masyarakat. Kajian Jurnal Dialog edisi ini diawali dengan tulisan Prof. Dr. H.M.
Atho Mudzhar tentang Instrumen Internasional dan Peraturan Perundangan Indonesia tentang Kebebasan dan Perlindungan Beragama. Dilanjutkan dengan tulisan Prof. Dr. Abdurrahman Mas'ud yang mengupas tentang Menyikapi Keberadaan Aliran Sempalan.

Sukris Sarmadi, Dosen STAIN Banjarmasin menghadirkan tulisan tentang Transformasi NU dalam Masyarakat Banjar Kini PerspektifPergeseran Gerakan Keagamaan di Kalimantan Selatan. Sedangkan M. Ulinnuha Khusnan, MA melalui tulisannya mencoba memotret Paradigma Keberagamaan Kaum Santri. Nurhasanah dosen UIN Jakarta menghadirkan tulisan tentang Politik Kebijakan Islamisasi Mahathir. Kajian jurnal dialog edisi ini kian lengkap dengan hadirnya tulisan Anwar Mujahidin, MA, tentang Science And Religion (Paradigma Al-Qur'an untuk IlmuIlmu Sosial Menurut Pemikiran Kuntowijoyo).

Di samping memuat artikel ilmiah, Jurnal Dialog edisi ini juga memuat laporan hasil penelitian oleh Ridwan Bustaman, tentang Analisis Wacana Kritis : Tayangan Kekerasan dalam Sinetron Bernuansa Keagamaan. Dan juga hasil penelitian saudara Basuki tentang Pesantren, Tasawufdan Hedonisme Kultural (Studi Kasus Aktualisasi Nilai-nilai Tasawuf dalam Hidup dan Kehidupan di Pondok Pesantren Modern Gontor). Serta hasil penelitian saudari Maryam tentang Interaksi Sosial Pelaku Konversi Agama Etnik Cina.

Kajian ini diakhiri dengan telaah 
buku yang mengulas buku karya Prof. Abdurrahman, 2009 yang berjudul Menebar Rahmat bagi Sekalian Alam. Semoga kajian yang dihadirkan Jurnal Dialog edisi ini memberikan manfaat yang berarti bagi para pembaca, khususnya dalam kajian Pergeseran Paradigma Menyoroti Gerakan Keagamaan. Selamat Membaca!

Redaksi

4 Dialog No. 68, Tahun XXXII, Nopember 2009 
TOPIK

M. Atho Mudzhar

Instrumen Internasional dan Peraturan Perundangan Indonesia tentang Kebebasan dan Perlindungan Beragama - -6

Abdurrahman Mas'ud

Menyikapi Keberadaan Aliran Sempalan --16

SUKRIS SARMADI

Transformasi NU dalam Masyarakat Banjar Kini Perspektif Pergeseran Gerakan Keagamaan di Kalimantan Selatan - 25

\section{Ulinnuha KhuSNAN}

Memotret Paradigma Keberagamaan Kaum Santri —41

\section{NuRHASANAH}

Politik Kebijakan Islamisasi Mahathir —65

\section{Anwar Mujahidin}

Science And Religion (Paradigma Al-Qur'An untuk Ilmu-Ilmu Sosial Menurut Pemikiran Kuntowijoyo) -78

\section{PENELITIAN}

\section{RidWAN Bustamam}

Analisis Wacana Kritis : Tayangan Kekerasan dalam Sinetron Bernuansa Keagamaan $\longrightarrow 97$

\section{BASUKI}

Pesantren, Tasawuf dan Hedonisme Kultural (Studi Kasus Aktualisasi Nilainilai Tasawuf dalam Hidup dan Kehidupan di Pondok Pesantren Modern Gontor) -112

MARYAM

Interaksi Sosial Pelaku Konversi Agama Etnik Cina --135

\section{BOOK REVIEW}

\section{Dewi $\mathbf{N}$}

Menebar Rahmat bagi Sekalian Alam —149 


\title{
Analisis Wacana Kritis: Tayangan Kekerasan dalam Sinetron Bernuansa Keagamaan
}

\author{
OLEH: RIDWAN BUSTAMAM*)
}

\begin{abstract}
Television program has been a cultural study since a long time ago due to the fact that television is a media which is purposed to educate, to inform, to entertain, and to control the society (religion), economy, and popular cultural ceremony. There will emerge some problems when the content and the message of a program does not fit with the audience's expectation, for instance, a religious program that has potency of conflict, controversy, and violence. All of those are categorized as breaking the rules, norm, and religious teaching. This study uses critical discourse analysis in order to examine relationship among discourse and audience, economical and political interest as well as an ideological aspect. This analysis is also utilized to examine the relationship between television and related institutions. Based on this reason, this research tries to explore religious cinema electronics on television which contains violence.
\end{abstract}

\section{Keywords:}

discourse analysis, impressions, violence, cinema electronics, religious

\section{Pendahuluan}

\section{A. Latar Belakang}

Era keterbukaan dalam masyarakat saat ini, terutama dalam hal industri kreatif seperti media televisi. Di satu sisi, ia membawa dampak positif karena peluang individu untuk berkreasi dan berekspresi makin besar. Terbukti bahwa masyarakat mulai "tergiur" atau mengapresiasi peran di bidang seni, juga hiburan seperti musik dan

\footnotetext{
*) Peneliti pada Puslitbang Lektur Keagamaan Badan Litbang dan Diklat Depag RI (ridwanbus@yahoo.com)
}

sinetron. Di sisi lain, dalam wacana kebudayaan, tayangan televisi dianggap sebagai budaya pop atau budaya "rendah"1. Sebab, budaya pop sering dituduh sebagai pendorong konsumtivisme. Lebih dari itu, budaya pop

\footnotetext{
${ }^{1}$ Apa pun istilah yang kita pakai, entah itu budaya massa, budaya tinggi, budaya kelas buruh, budaya substandar, budaya rakyat, atau budaya daerah yang tercakup ke dalam definisi budaya pop, seluruhnyadengan proporsinya masing-masing-akan membawa perubahan definisi secara teoritis dan politis terhadap budaya pop tertentu. Dalam John Storey. 2003. Teori Budaya dan Budaya Pop: Memetakan Lanskap Konseptual Cultural Studies. CV. Qalam, Yogyakarta.
} 
justru merupakan ajang pertarungan makna-makna sehingga ideology yang dominan bisa saja terusik, misalnya antara pemodal dengan produser, antara perempuan dengan laki-laki, termasuk antara seniman dengan lembaga keagamaan yang berlangsung terusmenerus.

Pada tataran praktis, pemilik stasiun televisi berupaya menyajikan acara bernuansa keagamaan yang bertujuan menghibur masyarakat. Tayangan televisi dikemas sedemikian rupa agar mencapai rating yang bagus di mata masyarakat. Namun secara konseptual, harus ada kode etik dan proses negosiasi atau kontrol terhadap isi tayangan televisi agar fungsi informatif, hiburan, dan pencerahannya tercepai sekaligus. Idealnya, para pengelola stasiun televisi semestinya melakukan proses negosiasi dengan para tokoh agama dan lembaga keagamaan terkait.

Di Indonesia sendiri sudah dikeluarkan regulasi berupa pedoman tayangan acara televisi yang cukup matang. Misalnya, dikeluarkannya Undang-Undang Republik Indonesia Nomor 32 Tahun 2002 tentang Penyiaran. Kemudian diperkuat oleh Peraturan Pemerintah Republik Indonesia Nomor 50 Tahun 2005 tentang Penyelenggaraan Penyiaran Lembaga Penyiaran Swasta, juga Peraturan Pemerintah Republik Indonesia Nomor 49 Tahun 2005 tentang Pedoman Kegiatan Peliputan Lembaga Penyiaran Asing. Demikian pula dengan dikeluarkannya Keputusan Komisi Penyiaran Indonesia Nomor 009/SK/KPI/8/ 2004 tentang Pedoman Perilaku Penyiaran dan Standar Program Siaran, yang kemudian disempurnakan oleh Peraturan Komisi Penyiaran Indonesia Nomor 02/P/ KPI/5/2006 tentang Pedoman Perilaku
Penyiaran dan Standar Program Siaran.

Jika dicermati UU Pers No. 40 Tahun 1999, ada 5 fungsi media yang berlaku di Indonesia, yaitu pendidikan, informasi, hiburan, kontrol sosial, dan ekonomi. Televisi adalah salah satu bentuk dari media massa yang berfungsi sebagai penyampai informasi kepada pemirsa. Media televisi tidak hanya bersifat informatif, tetapi juga bersifat hiburan atau entertainment, sekaligus sebagai persuasif, misalnya oleh para pemuka agama maupun budayawan dalam mempengaruhi publik. Televisi seharusnya ikut membentuk pemahaman publik atas semua problem kehidupan masyarakat. Ia semestinya menjadi meta-medium-sebuah instrumen yang tidak hanya mengarahkan pengetahuan pemirsa akan dunia - tetapi juga pengetahuan pemirsa akan cara mendapatkan pengetahuan itu sendiri. Sebab, audience televisi merupakan individu yang aktif dalam berinteraktif dengan televisi. ${ }^{2}$ Sayangnya, pada tataran praktis, fungsi ideal televisi masih jauh dari harapan, masih banyak stasiun televisi yang hanya menonjolkan aspek "hiburan". Bukan hanya itu, dalam banyak kasus, masyarakat justru menuding industri kreatif ini sebagai ajang "pembodohan" masyarakat, bukan sebagai media pencerahan dan transformasi sosial.

\section{B. Rumusan Masalah}

Perbedaan konseptual atau tafsir tentang tayangan ${ }^{3}$ kekerasan bernuansa

${ }^{2}$ Deddi Duto Hartanto. 2007. “Analisa Tayangan Kerajaan Sahur Trans TV sebagai Representasi Mass Culture", dalam jurnal NIRMANA, VOL.9, NO. 1, Januari 2007: 1-9.

${ }^{3}$ Tayangan atau siaran adalah pesan atau rangkaian pesan dalam bentuk suara, gambar, atau suara dan gambar atau yang berbentuk grafis, karakter, baik yang bersifat interaktif maupun tidak, yang dapat 
keagamaan selalu menjadi masalah dan perdebatan serius, baik pada tataran intern maupun antar lembaga terkait seperti Komisi Penyiaran Indonesia (KPI), pemerintah dan pemilik stasiun televisi, juga perdebatan di tingkat publik. Meskipun KPI sudah mengeluarkan berbagai aturan tertulis, namun pada tataran praktis belum terlihat kesepahamanan, bahkan konflik konseptual sering terjadi, terutama karena perbedaan ideologi ${ }^{4}$. Konflik tersebut misalnya ditandai oleh radikalisasi massa, yaitu protes dengan kekerasan yang dilakukan publik terhadap pelaku media massa. Penilaian negatif masyarakat terhadap isi tayangan televisi - terutama tayangan bernuansa keagamaan-beragam, baik dalam bentuk somasi, pengaduan, dan sebagainya. Semua itu merupakan bukti

diterima melalui perangkat penerima siaran. Lihat, Salinan Peraturan Komisi Penyiaran Indonesia Nomor 02/P/KPI/5/2006 tentang Pedoman Perilaku Penyiaran dan Standar Program Siaran.

${ }^{4}$ Pengertian Ideologi (Ideologie) adalah suatu sistem keyakinan, berpikir, dan pola sikap yang umumnya dipegang oleh suatu kelompok atau masyarakat. Ideologi merupakan cermin dari pandangan hidup, juga menjadi pedoman dalam hubungan sosial, etika, politik, serta ekonomi suatu kelompok atau masyarakat tersebut. Ideologi juga dipahami sebagai manifestasi dari bekerjanya sistem dan proses kekuasaan. Apabila kekuasaan itu sedemikian mengakar, ideologi diterima sebagai bagian yang tidak terpisahkan dari kehidupan seharihari, seakan-akan menjadi "akal bersama" (common sense) antara kelompok yang tersubordinasi dan penguasa. Kondisi semacam itu oleh Gramsci disebut sebagai ideologi hegemonis, yakni titik klimaks dari kemampuan serangkaian ide ataupun pendapat dari kelompok yang berkuasa untuk mempengaruhi keseluruhan elemen yang ada dalam masyarakat. (Abdullah, 1997). Singkatnya, sistem ideologi mempunyai hubungan langsung dengan pengalaman manusia hidup di dalam masyarakat secara total. Jadi ideologi itu tidak saja melingkupi bidang pengetahuan dan gagasan saja, tetapi juga meluas pada simbol, mitos, selera, gaya, fashion, iklan, televisi, media massa, interior rumah, mobil, dan seluruh 'cara hidup' suatu masyarakat. resistensi publik atas tayangan televisi yang mengandung bias.

Apa yang melatarbelakangi sehingga tayangan kekerasan itu sering muncul dalam sinetron bernuansa keagamaan? Dari mana akar ideologis yang menjadi sumber perdebatan terkait tayangan kekerasan dalam sinetron ${ }^{5}$ bernuansa keagamaan?

\section{Kerangka Teori \\ Analisis wacana ${ }^{6}$ (discourse analysis),}

${ }^{5}$ Sinetron merupakan pemendekan terminologi dari sinema elektronika. Ada banyak varian terkait terminologi ini, sebab ada juga yang menggunakan istilah lain seperti lakon televisi, TV play, telesinema, sinema televisi, dan sebagainya. Masing-masing pemakai istilah mempunyai argumen atas pilihan istilah tersebut. Lihat, Veven Sp Wardhana. "Perempuan dalam Sinetron Indonesia: Petaka atau Perkasa", dalam Ashadi Siregas dkk. 2000. Eksplorasi Gender dalam Ranah Jurnalisme dan Hiburan. LP3Y dan Ford Foundation, Yogyakarta. Penelitian ini sendiri memilih istilah sinetron, sebab istilah itulah yang paling akrab atau populer bagi para pemirsa televisi di Indonesia.

${ }^{6}$ Dalam pengertian sederhana, wacana adalah cara objek atau ide diperbincangkan secara terbuka kepada publik sehingga menimbulkan pemahaman tertentu yang tersebar luas. Dalam Alex Sobur. 2001. Analisis Teks Media: Suatu Pengantar untuk Analisis Wacana, Analisis Semiotik, dan Analisis Framing. PT Remaja Rosdakarya, Bandung. Dalam konteks ini, pengertian wacana sering disamakan dengan discourse. Kesamaan istilah ini misalnya ditemukan dalam pengertian yang dikemukakan Arkoun (1997) bahwa wacana adalah "cara manusia-pada periode, dan dalam golongan sosial atau bidang keahlian tertentu-membicarakan kenyataan". Istilah wacana juga dipakai untuk istilah pembicaraan itu sendiri. Dalam bahasa Indonesia kadang-kadang juga disebut diskursus. Discourse berbeda dari "bahasa" yang biasanya diartikan sebagai suatu "sistem" yang bersifat abstrak dan umum, dipergunakan untuk "alat" komunikasi oleh subjek yang mandiri sebagai konsumen (secara kreatif maupun mekanis). Suatu discourse akan berlangsung, jika terjadi "perjumpaan asumsi" antara mereka yang terlibat dalam kegiatan berbaku-tutur, bukan kesetiaan mematuhi tata bahasa yang universal. Perjumpaan asumsi seketika itu berlaku secara setempat, sesaat, dan sebatas kalangan yang langsung terlibat. Fairclough (1995) menegaskan bahwa wacana itu sendiri tidak hanya dilihat dari aspek kebahasaan, tetapi juga bagaimana bahasa itu diproduksi dan kemungkinan adanya ideologi tertentu dibaliknya. 
analisis semiotik ${ }^{7}$ (semiotic analysis), dan analisis bingkai ${ }^{8}$ (framing analysis) tergolong baru dalam khazanah penelitian empirik di Indonesia. Posisi ketiganya berada bersama-sama (saling melengkapi) untuk memahami berbagai komponen yang bermain dan mempengaruhi isi media (media content), khususnya yang menggunakan pendekatan kualitatif. Ketiga pendekatan tersebut merupakan upaya menjawab keterbatasan pendekatan paling awal, yaitu analisis isi "tradisional" (content analysis ${ }^{9}$ ) dalam

${ }^{7}$ Semiotic berasal dari kata semeiotics (Yunani: óçìaéûôéêüò, semeiotikos), artinya an interpreter of signs. Jadi, semiologi adalah ilmu tentang tafsir tanda, termasuk sistem tanda. Definisi ini membuat aplikasi semiologi sangat luas, bisa digunakan berbagai bidang keilmuan, karena semiologi adalah metoda tafsir untuk seluruh tanda yang diproduksi oleh manusia. Semiologi berkembang menjadi ilmu untuk menafsirkan berbagai hal berhubungan dengan tandatanda, termasuk berguna bagi analisis kritik ideologi. Dalam Andrik Puwasito. "Analisis Semiologi Komunikasi sebagai Tafsir Pesan". Jurnal Komunikasi Massa, Vol. 1, No. 1, Januari 2008.

${ }^{8}$ Alex Sobur (2001) menjelaskan bahwa analisis bingkai (framing) merupakan pendekatan baru analisis wacana, khususnya untuk menganalisis teks media. Gagasan mengenai framing pertama kali diperkenalkan oleh Beterson tahun 1955. Belakangan ini, konsep framing telah digunakan secara luas untuk menggambarkan proses penseleksian dan penyorotan aspek-aspek khusus sebuah realitas oleh media. Analisis framing merupakan perkembangan terbaru atau hasil elaborasi dari analisis wacana, yaitu studi yang menonjolkan pendekatan multidisipliner dalam menganalisis pesan-pesan tertulis maupun lisan. Analisis framing juga memungkinkan disertakannya konsep-konsep sosiologis, politik, dan kultural untuk menganalisis, memahami, dan mengapresiasi suatu fenomena komunikasi dalam berbagai media, baik tertulis maupun lisan.

${ }^{9}$ Content analysis is a tool for objective, systematic study of message content (analisis isi adalah teknik penelitian untuk mendeskripsikan secara obyektif, sistematik dan kuantitatif isi komunikasi yang tampak (Berelson, 1952). Pengertian yang lebih teknis menyatakan: content analysis is a research method for making replicable and valid reference from data or their contexs (Analisis Isi adalah suatu tekhnik penelitian untuk membuat inferensi-inferensi (cara data dikaitkan menganalisis isi pesan media, sebab analisisnya tidak sampai pada tataran ideologis.

Terkait hubungan media massa dengan ideologi, dengan mengutip Althusser, Eriyanto ${ }^{10}$ mengatakan bahwa dalam konteks ideologi modern, media akan banyak berperan sebagai ideological state apparatus. Artinya, media massa berfungsi sebagai ranah dan dasar pembenaran praktek hegemoni negara terhadap warganya. Untuk itu, analisis wacana yang tepatnya disebut Critical Discourse Analysis (CDA), tidak saja mampu melakukan textual interrogation, tetapi juga mampu mempertautkan hasil interogasi tersebut dengan konteks makro yang tersembunyi di balik wacana. Hasil kerja analisis wacana merupakan academic exercise dalam rangka penyadaran, pemberdayaan, pencerahan, dan transformasi sosial.

Analisis wacana pada akhirnya bukan hanya bidang kajian mereka yang berlatar belakang Ilmu Komunikasi. Akan tetapi, analisis wacana menghasilkan kajian yang bersifat multidisipliner, khususnya dalam lingkup ilmu-ilmu sosial, humaniora, dan sastra yang lebih

dengan konteksnya) yang dapat ditiru (replicable) dan sahih data dengan memperhatikan konteksnya). [Krippendorff, 1991]. Objek yang diteliti adalah: (1) kata-kata, ucapan, suara; (2) tulisan (kata, kalimat, paragraf atau keseluruhan isi, symbol dsb); (3) visual (gambar bergerak/berjalan); (4) foto (gambar); (5) gerakan (mencibir, menghindar, memukul, menendang, membanting dsb); (6) adegan (merajuk, memeluk, mencium, mengelus, dsb); (7) thema (tematema cinta, humor, tragedi, kolosal dsb); (8) gagasan/ ide (HAM, lingkungan hidup, kesetaraan gender, pelayanan prima, demokrasi, keterbukaan, kebebasan pers, dsb). Dalam Juwono Tri Atmodjo. t.t. Analisis Isi (Content Analysis). Dalam Modul Riset $P R$ Fikom - Universitas Mercubuana Jakarta.

${ }^{10}$ Eriyanto. 2001. Analisis Wacana: Pengantar Analisis Teks Media. LKis, Yogyakarta 
menekankan sifat holistik dan kontekstual. $^{11}$

Dalam penerapannya, metode analisis wacana sudah sangat akrab dengan para peneliti media dan komunikasi. Dalam kaitannya dengan analisis wacana keagamaan di media, dapat disebutkan beberapa kajian terdahulu, antara lain: (1) Deddi Duto Hartanto (2007), "Analisa Tayangan Kerajaan Sahur Trans TV sebagai Representasi Mass Culture", dalam Jurnal NIRMANA, VOL.9, No. 1, Januari 2007: 1-9; (2) Isna Siskawati (2006) berjudul Komodifikasi Nilai-Nilai Agama dalam Sinetron: Analisis Wacana Kritis terhadap Sinetron Takdir Ilahi di TPI, Tesis Program Pascasarjana Universitas Indonesia; (3) Ade Rina Farida (2004), Konstruksi Realitas Islam Liberal dalam Media Cetak: Analisis Framing Majalah Gatra dan Sabili, Tesis Program Pascasarjana Universitas Indonesia; (4) Buku hasil penelitian oleh M. Hamdar Arraiyyah dan Rosehan Anwar (2000) berjudul Wacana Keagamaan di Surat Kabar: Pesan dan Respons Pembaca. Pusat Penelitiaan Lektur Agama, Badan Litbang Agama dan Diklat Keagamaan. Sedangkan artikel yang terkait dengan penelitian ini antara lain yang ditulis oleh A. Nunuk Prasetyo Murniati (2000), “Kekerasan terhadap Perempuan dalam Wacana Keagamaan: Tinjauan dari Agama Katolik Roma", dalam Seminar Nasional Peran Agamaagama dalam Upaya Penghapusan Kekerasan terhadap Perempuan, Jakarta. Selain itu, banyak pula penelitian tentang analisis wacana di media, namun isu dan tema yang diangkat lebih bersifat umum atau tidak berkaitan

${ }^{11}$ Dedy N. Hidayat, pengantarnya terhadap buku Eriyanto (2001). secara spesifik dengan wacana keagamaan dalam bentuk sinetron.

Berbeda dengan penelitian sebelumnya, tulisan ini lebih fokus pada analisis wacana kritis (Critical Discourse Analysis) terhadap tayangan kekerasan dalam sinetron bernuansa keagamaan. Dalam konteks ini, wacana di sini tidak dipahami sebagai studi bahasa. Analisis wacana kritis memiliki karakteristik antara lain: (1) wacana merupakan suatu tindakan (action); (2) mempertimbangkan konteks seperti situasi dan kondisi; (3) mempertimbangkan wacana dalam konteks sosial tertentu; (4) memperhatikan elemen kekuasaan (power); (5) teks, percakapan, dan lainnya merupakan pencerminan dari ideologi tertentu. Hal yang dicoba ungkap adalah pertarungan perspektif dan ideologi yang terefleksi dari tayangan kekerasan dalam sinetron bernuansa keagamaan.

\section{Tujuan dan Manfaat Penelitian}

Penelitian ini bertujuan mengungkap hakikat dari tindakan (action), konteks (situasi dan kondisi), historis (konteks sosial tertentu), elemen kekuasaan (power), dan ideologi tertentu yang terefleksi dari tayangan kekerasan sinetron bernuansa keagamaan. Penetian ini diharapkan dapat memberi masukan bagi pelaku industri kreatif, sekaligus sebagai bahan pertimbangan bagi institusi yang berwenang dalam mengawasi program dan tayangan di media, khususnya televisi.

\section{Metode Penelitian}

A. Tempat dan Waktu Penelitian

Penelitian ini difokuskan pada program siaran televisi nasional yang dapat dinikmati langsung oleh masyarakat Jabodetabek saat ini. 
Program stasiun televisi tersebut selalu diinformasikan di berbagai surat kabar nasional seperti KOMPAS, REPUBLIKA, KORAN TEMPO, dan sebagainya tentang jadwal acara di TVRI, RCTI, SCTV, INDOSIAR, TPI, TRANS TV, TRANS 7, ANTV, TVONE, METRO TV, dan GLOBAL TV. ${ }^{12}$

Program siaran yang dikaji adalah tayangan sinetron bernuansa keagamaan yang dijadwalkan televisi secara rutin selama sepekan. Namun demikian, karakteristik sinetron tersebut umumnya cerita berseri, baik yang penayangannya memakan waktu berbulan-bulan bahkan bertahuntahun (berjilid).

\section{B. Cara Pengumpulan Data}

Ada tiga langkah yang ditempuh, yaitu: (1) mengeksplorasi data dan

\footnotetext{
${ }^{12}$ Masyarakat Jabodetabek saat ini terdapat menikmati langsung 16 stasiun televisi tanpa harus berlangganan, yaitu: TVRI, RCTI, SCTV, INDOSIAR, TPI, TRANSTV, TRANS 7, ANTV, TVONE, METROTV, GLOBAL TV, O CHANNEL, JAK TV-7, DAAI TV, dan SPACE STOON. Selain itu, tercatat sejumlah televisi komunitas sedang mengurus perijinan ke Komisi Penyiaran Indonesia. Bahkan sudah ada yang mendapat ijin prinpip penyelenggaraan penyiaran, yakni Candradimuka TV, dari Sekolah Tinggi Ilmu Sosial Candradimuka, Palembang yang telah mengantongi ijin penyelenggaraan penyiaran sejak tanggal 23 Sepember 2008 lalu. Sementara Untirta TV dan IAIN TV di Banten baru mengantongi rekomendasi dari KPID setempat, menunggu hasil Forum Rapat Bersama antara Pemerintah (Depkominfo) dan KPI Pusat. Al Washilah TV yang bermarkas di Kembangan, Kebon Jeruk, Jakarta telah mendapat verifikasi faktual dari KPI. Sedangkan 7 (tujuh) televisi komunitas di Jawa Barat, yakni yakni SEDCTV, Televisi Pendidikan Kota Cimahi, Panguyuban Komunitas TV Nusantara (TVB), Televisi Komunitas Pendidikan KIJARA, Televisi Komunitas Universitas Gunadharma, Komunitas Study Broadcasting Television (SBC TV), dan Televisi Komunitas SPENSA, telah melalui proses pra-FRB (Forum Rapat Bersama) antara Depkominfo dan KPI. Lihat, Budhi Hermanto. 2008. “Televisi Komunitas Sebuah Media Alternatif", http://www.kabarindonesia.com, 08-Mar2008
}

informasi di seputar penilaian negatif masyarakat terhadap isi tayangan televisi bernuansa keagamaan, termasuk somasi, demonstrasi, surat pembaca, pengaduan, dan bentuk-bentuk "resistensi" publik lainnya atas suatu tayangan; (2) melakukan kajian pustaka untuk menelusuri data-data sekunder, yaitu buku teks, terbitan berkala seperti jurnal, majalah, dokumen, makalah, dan data-data yang diperoleh dari penelusuran website. Sedangkan unit analisis datanya adalah jadwal siaran rutin televisi nasional dalam satu minggu yang diperoleh dari berbagai surat kabar nasional, yaitu jadwal siaran televisi pada awal bulan Agustus 2009. Jadwal tersebut dipilih karena biasanya menjelang bulan bulan Ramadan, hampir seluruh stasiun televisi mencoba merespons programprogram bernuansa keagamaan; (3) melakukan pengamatan langsung tentang tayangan kekerasan bernuansa keagamaan, terutama yang sering ditonjolkan dalam sinetron bernuansa keagamaan.

\section{Metode Analisis Data}

Metode analisis data yang digunakan dalam penelitian ini adalah analisis kualitatif. Sesuai dengan tema yang dibahas, jenis analisis data yang digunakan adalah analisis wacana, analisis semiotik, ataupun analisis bingkai yang penerapannya disesuaikan dengan jenis data maupun fenomena yang ditemukan.

\section{III.Hasil Penelitian}

\section{A. Gambaran Umum}

Terlepas dari karakter yang dimiliki masing-masing stasiun televisi, kehadirannya di ranah privat cukup menebar pesona. Televisi selalu beru- 
paya mengemas program acaranya agar menarik seperti musik, film, telenovela, sinetron, iklan, dan "pemberitaan". Menjelang Ramadan tahun 2009 ini saja, tayangan sinetron berseri di stasiun televisi, terutama yang sudah mapan, menunjukkan trend atau kecenderungan yang sama dengan tahun-tahun sebelumnya. Secara umum dapat digambarkan bahwa ada 3 stasiun televisi yang kemasan programnya lebih banyak diisi dengan tayangan sinetron. Terbanyak adalah televisi Indosiar, tercatat 7 judul sinetron berseri yang ditayangan setiap harinya, yaitu: Impian Sang Putri; Kasih dan Amara; Tangisan Isabela; Mualaf; Inayah; Tasbih Cinta, dan; Angling Dharma; termasuk Jiran (ketika penelitian ini dilakukan belum tayang atau sedang diiklankan). Menyusul kemudian RCTI dan SCTV, sinetron yang ditayangkan kedua stasiun televisi ini mencapai 6 judul setiap harinya. RCTI menayangkan judul sinetron seperti Tarzan Cilik; Manohara; Cinta dan Anugerah; Dewi; Janji (2 $\left.{ }^{\text {nd }}\right)$, dan; Aisyah $\left(2^{n d}\right)$. Sedangkan SCTV menyuguhkan sinetron berjudul: Kepompong; Lemontea Asam Manis Cinta; Melati untuk Marvel; Cinta Fitri Season Ramadan; Terlanjur Cinta, dan; Inikah Cinta. TPI yang mengusung tema sebagai televisi pendidikan juga menayangkan sinetron berjudul: Sinetron Spesial Ramadan: Mukjizat Cinta; Kumpulan Kisah Hikmah Hijrah, dan; Ronaldowati Babak 2. TVRI juga ikut merayakannya dengan sinetron lepas berdurasi 30 menit setiap hari Senin sampai Jumat. Sementara itu, beberapa stasiun memberikan porsi tayangan sinetron secara terbatas, seperti sinetron Suami-Suami Takut Istri yang disiarkan Trans TV, juga sinetron Abdel E Temon Bukan Superstar yang ditayangkan oleh Global TV. Stasiun-stasiun televisi seperti TVONE, Metro TV, Trans7, termasuk ANTV, JAK TV, O Channel, DAAI TV, dan Space Toon lebih memilih untuk membangun program siaran yang lebih berkarekter.

Dengan demikian, saat ini tercatat sekitar 22 judul sinetron yang sedang tayang di stasiun-stasiun televisi swasta (termasuk 1 sonetron lepas di TVRI) di Indonesia. Sinetron-sinetron tersebut mewakili dua karakter utama. Pertama, karakter cerita yang bersifat terbuka, yaitu sinetron yang rangkaian episodenya mengalir begitu saja. Setiap episode menampilkan jalinan cerita yang berbeda. Tidak terlihat perspektif tertentu yang dicoba terapkan untuk pemecahan masalah, baik dari awal episode hingga sinetron tersebut berakhir. Kedua, karakter cerita yang menonjolkan relasi interpersonal pemainnya. Cerita sinetron terpusat pada hubungan pribadi manusia: pertikaian keluarga, jatuh cinta, pernikahan, perpecahan, poligami, perselingkuhan, balas dendam, dan sebagainya. Namun demikian, terdapat kecenderungan bahwa ceritanya berpangkal pada persoalan cinta dan segenap romantismenya.

Dalam konteks penelitian ini, isi cerita yang dikategorikan bernuansa keagamaan yang cukup menonjol di antaranya berjudul: (1) Mualaf dan Inayah yang ditayangkan Indosiar; (2) Aisyah (2 ${ }^{\text {nd }}$ ) oleh RCTI; (3) Cinta Fitri Season Ramadan oleh SCTV, dan; (4) Sinetron Spesial Ramadan: Mukjizat Cinta; juga Kumpulan Kisah Hikmah Hijrah yang ditayangkan oleh TPI.

\section{B. Analisis Data}

Semenjak pertengahan tahun 2004, televisi di Indonesia banjir dengan sinetron religius bertajuk "Ilahi". 
Diawali dengan sukses TPI menayangkan serial Rahasia Ilahi, yang konon diilhami dari kisah-kisah nyata dalam majalah Hidayah. Sinetron religius semacam ini ternyata mampu mendongkrak peringkat rating televisi bersangkutan. Tak heran jika kemudian hampir semua stasiun TV menayangkan sinetron sejenis. Berdasarkan sumber ceritanya, ada sinetron yang didasarkan pada kisah nyata. Misalnya, Rahasia Ilahi di TPI, Astaghfirullah di SCTV, Taubat di Trans-TV, juga Azab Ilahi dan Sebuah Kesaksian di Lativi. Selain itu, ada pula yang mengambil ide ceritanya dari sumber-sumber Islam klasik, berdasarkan hadis yang dianggap sahih. Selain itu, sumber ceritanya ada juga yang diambil dari kitab-kitab klasik. Takdir Ilahi di TPI misalnya, ceritanya merujuk kepada hadis Bukhari-Muslim. Pelaku industri kreatif ini pun berupaya mendapatkan legitimasi publik dengan menghadirkan seorang kiai, dai, atau agamawan yang dianggap dapat memberi tafsir kontekstual di akhir tayangannya. Meskipun terkesan masih berupa tafsir literal dan lebih menekankan kesalehan ritual, komentar para kiai dan dai ini agaknya menarik perhatian penonton, setidaknya dapat menambah "kepercayaan" penonton bahwa tayangan tersebut benar-benar bertujuan dakwah, bukan semata-mata bisnis.

Sampai di sini sebenarnya tak ada persoalan. Bahkan seoleh-oleh kisah sinetron tersebut dapat memuaskan kegelisahan para pemirsa terhadap problematika yang dialaminya. Namun demikian, jika ditelaah secara lebih mendalam, akan terungkap berbagai kontradiksi seperti alur cerita yang tidak logis, penulisan skenario yang terkesan "kejar tayang", dan penafsiran simbolsimbol formal keagamaan tertentu yang tidak relevan dengan konteks ajaran agamanya, tanpa pemaknaan lebih mendalam atas pesan-pesan kemanusiaan yang terdapat dalam ajarannya. Untuk itu, tidak tepat jika agama dimobilisasi untuk melegitimasi strategistrategi "sinis" yang dihasilkan oleh dominasi politik dan ekonomi. ${ }^{13}$

Dari perspektif komunikasikhususnya riset media-teridentifikasi suatu kecenderungan perilaku industri kreatif. Ketika Ramadan menjelang, fenomena maraknya penggunaan simbol-simbol keagamaan selama Ramadan menyisakan sejumlah pertanyaan yang menarik untuk dieksplorasi. Sepanjang Ramadan, televisi berupaya menyajikan tayangan unggulan (prime time) yang diperebutkan stasiun televisi dan para pengiklan. Rekonfigurasi jam tayang ini pada akhirnya menimbulkan konsekuensi lain, yaitu perubahan konfigurasi acara. Bahkan, ada program yang dihapus sementara waktu karena tayangannya dianggap "vulgar" seperti cerita berseri berjudul Curhat, juga serial Komedi Tangah Malam di LaTivi. Demikian pula serial Baywatch di RCTI yang mengisahkan kehidupan para penjaga pantai yang memakai bikini.

Selain itu, karakter aktris yang biasanya berbusana glamor "mendadak" menjadi lebih "Islami" di bulan Ramadan (saja), terutama ketika membawakan acara-acara bernuansa keagamaan atau keislaman. Kalangan selebritis ikut-ikutan pula menggunakan jilbab. Penggunakan

${ }^{13}$ Ruslani. “Dari Sinetron Religius ke 'Emerging Reaso". Dalam Harian Kompas, Sabtu, 01 Oktober 2005. 
jilbab di sini tentunya dilatarbelakangi oleh berbagai kepentingan. Misalnya, sekadar memenuhi tuntutan skenario, iklan, dan sejenisnya. Penggunaan jilbab di sini jelas tidak didasari oleh kesalehan beragama. Sebab, setelah Ramadan berlalu, mereka pun melepas jilbab sekonyong-konyong. Migrasi simbolik para artis tersebut menunjukkan keterbatasan pemaknaan bahwa keislaman dapat diwakili oleh "simbol" busana muslim. Selain itu, sinetron merupakan ajang bagi "perangsangan" semangat konsumerisme, misalnya melalui penayangan kuis di setiap segmennya.

Kecenderungan pemaknaan dan perilaku industri kreatif di atas tidak berbeda jauh dengan hasil penelitian tahun 2006. Secara substansi, ide ceritanya tidak berubah, hanya nama acara dan setting programnya saja yang dikembangkan. Selebihnya sama saja. Genre program tetap didominasi oleh variety show dengan pendekatan komedi situasi. Konteks sosial yang direpresentasikan tetap saja kalangan menengah ke atas, demikian pula komunikator utamanya-tetap didominasi para artis atau pelawak. Gagasan ke arah "pencerahan" malah semakin kabur dalam Ramadan 2006. Bahkan, gagasan-gagasan kontroversial mulai subur. Misalnya, memparodikan sosok ulama yang populer. Ini terlihat dalam program Sana Sini Sahur (SCTV). Niat untuk meningkatkan kualitas program/siaran bernuansa keagamaan pun akhirnya berubah menjadi paradok. Sebab, religiusitas itu semestinya disampaikan secara verbal maupun non verbal. Dalam program sahur tersebut, terjadi "pelecehan" verbal dalam menyampaikan wacana keagamaan. Ketidaksantunan berperilaku, terutama dalam menata content pesan yang disampaikan begitu menonjol. Contohcontoh dalam kuis maupun "banyolan" antar artis sering mengandalkan bentuk-bentuk kekerasan verbal. Fenomena tersebut biasanya berlangsung secara spontan ketika Ramadan menjelang. Kontekstualitas agama sebaliknya dijadikan dalih untuk menghasilkan program Ramadan, yang pada dasarnya adalah produk industri budaya televisi yang dikerangka para kapitalis media untuk kepentingan kapitalisme. ${ }^{14}$

Pada tahun 2007, tayangan Ramadan di layar kaca kembali membuat masyarakat meradang. Sebagai wakil lembaga keagamaan umat Islam, Majelis Ulama Indonesia (MUI) menilai masih banyak program siaran televisi nasional yang tidak sesuai dengan realitas umat Islam, khususnya berkaitan dengan dimensi pornografi, kekerasan, dan mistik. Berdasarkan hasil pemantauan MUI terhadap program siaran televisi swasta yaitu SCTV, TPI, RCTI, Indosiar, Trans-7, ANTV, Lativi, dan Global TV pada sepuluh hari pertama Ramadan. Ditemukan sekitar $90 \%$ tayangan televisi yang dapat merangsang budaya pacaran kepada anak usia sekolah atau remaja. Ironisnya, siaran yang dinilai MUI tidak layak tonton tersebut diklaim bagitu populer di masyarakat. Misalnya, sinetron Cowok Ideal dan Cinta Lama Bersemi Kembali yang ditayangkan SCTV, juga sinema asyik Legenda Buta Kala (TPI), serta Stasiun Ramadan di RCTI.

${ }^{14}$ Santi Indra Astuti. 2005. "Ramadhan dalam Bingkai Religius di Televisi: Kajian atas Kognisi Sosial, Mode Produksi, dan Fenomena Infotainment dalam Program Sahur". Tesis UI, Jakarta. Data hasil penelitian ini kemudian diupdate pada tahun 2006, dalam http://communicare-santi.blogspot.com/2007 
Mulai tahun 2007, sikap MUI lebih kritis terhadap tayangan televisi. MUI memantau setiap tayangan dan melaporkan temuannya ke Komisi Penyiaran Indonesia. Sebelumnya, metode apresiatif berupa pemberian award ke sejumlah acara televisi, ternyata tidak efektif dalam memperbaiki kualitas acara. Respons pengelola televisi dalam menyikapi kritik MUI juga berbedabeda. Sebagian stasiun televisi menunjukkan niat baiknya dengan membenahi program secara terbatas, khususnya pada siaran acara langsung (live). Sebagian lagi tidak menunjukkan kesungguhan untuk membenahi siarannya, bahkan makin berani menayangkan program yang bernuansa kekerasan, mistik, dan mengeksploitasi rangsangan libido. Ada pula televisi yang mengedepankan program yang konstruktif dan kondusif sejak awal Ramadan. Tidak dapat dihindari bahwa di satu pihak televisi merupakan mesin penyebar nilai spiritualitas, tetapi sekaligus ia bertindak sebagai wahana berlangsungnya pemalsuan, distorsi, dan konsumeristis. ${ }^{15}$

Tahun 2007, tim peneliti komunikasi dari Universitas Islam Bandung juga melakukan penelitian terhadap dua mata acara yang diklaim religius. Soleha, judul sinetron serial yang dibintangi Marshanda diputar oleh RCTI sesaat sesudah berbuka puasa. Sebagai tandingannya, sinetron Ustadz Ganteng Bikin Ge-er diputar SCTV untuk mengisi slot waktu ngabuburit (menjelang berbuka puasa). Penelitian ini mencoba membuktikan dugaan masih terjadinya "kekerasan", baik fisik maupun

15 Teguh Imawan, "Tayangan TV: Kematian Spiritualitas Ramadan". Didownload jam 11.00 tanggal 2 agustus 09 di http://epajak.org/abg/new/ moralitas/page/2 psikologis dari sinetron yang diklaim religius tersebut. Hasilnya, dalam satu episode sinetron Soleha (berdurasi 40 menit), adegan kekerasan terjadi sebanyak 28,75 persen dari total durasi. Kekerasan yang bersifat fisik teridentifikasi justru lebih menonjol. Sedangkan kekerasan psikologis berupa bentakan, ancaman, dan intimidasi lebih sedikit. Pelaku kekerasan itu sendiri didominasi oleh karakter laki-laki. Sementara itu, dalam Ustadz Ganteng Bikin Ge-er, adegan kekerasan justru lebih banyak lagi. Tercatat 16 kali pemunculan adegan kekerasan (selama 27,5 menit durasi) atau 36,67 persen dari total 75 menit durasi tayangan. Bukan hanya itu, adegan kekerasan seksual bahkan muncul sekitar 5 menit atau 7\% dari keseluruhan durasi cerita. Adegan tersebut mengisahkan seorang pekerja seks komersial yang disuruh merayu, memaksa, menggoda, dan melecehkan sang ustadz. Artinya, tingkat "religiusitas" kedua sinetron itu baru sebatas pemakaian simbol-simbol agama, meskipun tempat shooting tempat di musala atau masjid, ditayangkan pada bulan Ramadan, perempuannya berjilbab, sedangkan laki-laki menggunakan baju koko dan kopiahnya, dan seterusnya. ${ }^{16}$

Jika dicermati kasus-kasus yang terjadi belakangan, pertarungan ideologi wacana keagamaan dalam sinetron masih terus berlangsung. Iksander ${ }^{17}$ mengilustrasikan bahwa pada tanggal 24 maret 2009, Komisi Penyiaran Indonesia (KPI) Pusat melayangkan teguran kepada Indosiar. Intinya, agar mereka

${ }^{16}$ Agus Rakasiwi. 2007. "Ramadan dan Televisi Kita". Didownload jam 11.05 tanggal 2 agustus 09 di http://www.pikiran-rakyat.com/

${ }^{17}$ Didownload jam 14.40 tgl 8 agustus 2009 di http://www.ubb.ac.id/ 
memperbaiki materi sinetron Hareem yang penuh adegan kekerasan verbal maupun fisik. Indosiar pun berinisiatif menghentikannya mulai Selasa, 31 Maret 2009. Selain Hareem, KPI Pusat juga menetapkan enam sinetron yang tayang pada Januari 2009 sebagai sinetron bermasalah. Tiga di antaranya dikategorikan "berat", yaitu sinetron Suami-suami Takut Istri (Trans TV), sinetron Muslimah (Indosiar), juga Abdel dan Temon (Global TV). Sedangkan Alisa (RCTI), Tawa Sutra Siang (ANTV), dan Monalisa (Indosiar) dianjurkan memperbaiki materi siaran. Teguran tersebut muncul karena dinilai tidak memperhatikan norma-norma kesopanan, kesusilaan, dan berindikasi melanggar kaidah-kaidah agama, bahkan dinilai telah melecehkan ajaran Islam. MUI menyatakan bahwa sinetron tersebut melecehkan citra Islam lewat perilaku buruk pemainnya. Fenomena tersebut dianggap oleh KPI sangat berbahaya karena dinilai dapat menyinggung perasaan umat Islam di Indonesia. Ihwal mengolah "tanda" (simbol) dalam sinetron tersebut tampaknya tidak relevan, terutama dengan konteks keyakinan, ajaran, dan tradisi Islam. Sebagai contoh, signifier (penanda) berupa sosok wanita bengis, penuh makian, dan iri dengki disandingkan dengan simbol jilbab. Ada pertentangan "tanda" dan "penanda" yang bisa memprovokasi ajaran tertentu. Artinya, tayangan kekerasan bernuansa keagamaan dapat mengaburkan pandangan dan pemahaman tentang nilai-nilai keagamaan tertentu.

Menjelang Ramadan tahun 2009 ini, fenomena "anjing menggonggong kafilah berlalu" ternyata sudah knonis di dunia industri kreatif tersebut. Persoalannya malah menjadi lebih krusial lagi, sebab fenomena pelecehan terhadap ajaran agama justru ditemukan dalam sinetron yang bernuansa keislaman. Bukan hanya itu, penayangan adegan kekerasan yang jauh dari realitas umat Islam tetap ditonjolkan. Sinetron Mualaf misalnya, menceritakan tentang menantu laki-laki yang menganiaya mertuanya sampai lumpuh, padahal mertuanya adalah seorang Muslimah yang saleh. Sering pula ditemukan adegan pemukulan atau makian terhadap istri yang salehah. Menonjolkan perilaku poligami seorang suami, sementara istri pertamanya yang salehah dianiaya dan "dikerjai" oleh istri kedua. Konflik rumah tangga yang tidak berujung ini begitu kental dalam sinetron Mualaf.

Dalam versi lain, Indosiar juga menyuguhkan sinetron Muslimah yang kecenderungan ide, tema, dan kisahnya serupa. Sinetron ini mengisahkan dendam seorang kakak tiri perempuan kepada adik tiri perempuannya yang baik hati (mengenakan jilbab). Motif kekerasan muncul karena kakaknya dibakar api cemburu. Di antara adegan kekerasan yang tidak masuk akal adalah menabrak adik tirinya dengan mobil, menampar, mendorong, memaki-maki, bahkan menyewa pembunuh bayaran agar niatnya tercapai.

Bukan hanya itu, Indosiar juga menayangkan sinetron Inayah yang lagi-lagi berindikasi melecehkan ajaran agama Islam. Termasuk sinetron Jiran yang ketika penelitian ini dilakukan masih berupa iklan. Singkatnya, sinetron ini mengisahkan seorang suami yang berpoligami. Konflik yang menonjol adalah perebutan harta suami oleh istri-istrinya. Sosok istri yang saleh (yang disimbolkan dengan jilbab) lagilagi menjadi objek kekerasan dan 
pelecehan. Adegan tamparan, umpatan, dan intimidasi, termasuk menyewa pembunuh bayaran selalu meninpa sosok seorang istri yang salehah. Sinetron yang menggunakan simbolsimbol agama tersebut hanya menampilkan wajah bengis, dendam, perebutan harta dan kekuasaan melalui kekerasan verbal. Sinetron juga selalu menyuguhkan kehidupan yang mewah, glamor, pop dan sejenisnya yang sangat bertentangan dengan realitas masyarakat Indonesia.

\section{Pembahasan Hasil Penelitian}

Dalam konteks industri kreatif, produk berupa surat kabar, televisi, buku, video, film, sinetron, pemirsa dan seterusnya merupakan sumber daya (resource) untuk didistribusikan ke publik untuk dikonsumsi. Proses produksi, distribusi, dan konsumsi dalam industri media massa ini tentunya melibatkan berbagai relasi seperti jurnalis, organisasi media, pemilik modal atau kapitalis dalam perspektif ekonomi, dan negara - atau tepatnya pemerintah dalam perspektif politik. Namun pada era globalisasi saat ini, imperialisme media bahkan meliputi dimensi ekonomi, ideologi, politik, dan kultural. Di sini media menjadi ajang bagi para produser isi media untuk menggunakan komodifikasi nilai-nilai yang layak diperjualbelikan dalam pasar yang kompetitif.

Di Indonesia, memperbincangkan regulasi media tidak dapat serta merta melepaskan tiga varian utama, yaitu negara (state), pasar (market), dan masyarakat (society). ${ }^{18}$ Hubungan di

${ }^{18}$ Nawiroh Vera. t.t. "Ekonomi Politik Regulasi Media (RUU Anti Pornografi dan Pornoaksi)", makalah pada Fakultas Ilmu Komunikasi Universitas Budi Luhur. antara ketiganya bisa harmonis, dalam arti terdapat hubungan simbiosismutualisme yang interaktif, saling mengisi, dan tidak mendominasi. Sebagai fungsi regulator, negara berhak dan memiliki wewenang mengatur kebijakan media sehingga menguntungkan semua pihak. Pada tahap ini, fungsi negara menjadi vital untuk merumuskan kebijakan media yang tidak saling mendominasi di antara ketiganya.

Sebagai contoh, dalam Salinan Peraturan Komisi Penyiaran Indonesia Nomor 02/P/KPI/5/2006 tentang Pedoman Perilaku Penyiaran dan Standar Program Siaran, pada Pasal 2 dinyatakan: "Pedoman Perilaku Penyiaran dan Standar Program Siaran ditetapkan berdasarkan pada nilai-nilai agama, nilai-nilai moral, norma-norma lain yang berlaku dan diterima oleh masyarakat umum, berbagai kode etik, standar profesional dan pedoman perilaku yang dikembangkan masyarakat penyiaran, serta peraturan-perundangan yang berlaku, misalnya Undang-undang Nomor 32 Tahun 2002 tentang Penyiaran, UndangUndang Nomor 8 Tahun 1992 tentang Perfilman, Undang-undang Nomor 40 Tahun 1999 tentang Pers, dan Kitab Undangundang Hukum Pidana". Sedangkan pada Pasal 6: Pedoman Perilaku Penyiaran, menentukan bahwa standar isi siaran antara lain: (1) rasa hormat terhadap pandangan keagamaan; (2) rasa hormat terhadap hal pribadi; (3) kesopanan dan kesusilaan; (4) pelarangan dan pembatasan adegan seks, kekerasan, dan sadisme; (5)perlindungan terhadap anak-anak, remaja, dan perempuan; (6) ketepatan dan kenetralan program berita.

Dengan demikian, nilai seni dalam masyarakat memiliki wawasan etika- 
politik, kognitif, dan libido estetik yang bersifat integratif. Keputusan-keputusan yang berkaitan dengan politik-etik tidak dapat dianggap sebagai satu putusan intuitif atau individual, akan tetapi harus melibatkan pengetahuan tentang posisi sosial sebatang tubuh, atau struktur kehidupan sosialnya sehingga seorang individu (seniman misalnya) memiliki pengetahuan mengenai apa yang 'pantas', 'kurang pantas', dan 'tidak pantas' dilakukan dalam kerangka hubungan sosial.

Selain itu, seni memisahkan diri dari batasan-batasan etika, sosial, politik yang ada, dan berupaya membangun 'lembaga' seni yang otonom. Wacana seni yang otonom ini menghasilkan bentuk-bentuk seni yang tidak saja melepaskan diri dan menentang representasi sosial, akan tetapi berupaya membangun kriteria dan landasan normatif di dalam, dari dan untuk seni itu sendiri. Seni mendapatkan status otonomnya dengan cara menciptakan bentuk-bentuk yang dibebaskan dari setiap batasan tradisi dan kanon, serta dari setiap batasan norma sosial. Untuk itu, seni harus mengangkat kembali ke permukaan masalah yang menyangkut fungsi sosial, komunikasi, dan politik seni, terutama 'ideologi seni'.

Dalam kaitan ini, Camille Paglia mengatakan, "The mass media is completely, even servely commercial. It is a mirror of the popular mind (media massa sama sekali bersifat komersial, bahkan menjadi budak dari komersialisme itu sendiri. Ia merupakan cermin dari kesadaran popular)". ${ }^{19}$ Artinya, ekonomi kapitalisme mutakhir telah

${ }^{19}$ Camille Paglia. 1992. Sex, Art and American Culture. Viking, London \& New York, hlm. ix berubah ke arah penggunaan 'tubuh' dan 'hasrat' sebagai titik sentral komoditi, yang disebut dengan 'ekonomi libido' atau naluri seksual sebagai dorongan kehidupan yang paling mendasar. Tubuh menjadi bagian dari semiotika komoditi kapitalisme, yang memperjualbelikan tanda, makna, dan hasratnya. Dalam wacana media, wanita diposisikan bukan sebagai 'subjek' pengguna bahasa, tetapi sebagai 'objek tanda' (sign object) yang dimasukkan ke dalam 'sistem tanda' (sign system) dalam 'sistem komunikasi ekonomi' kapitalisme. Dalam jagad budaya yang didominasi oleh akumulasi kapitalisme. Akhirnya, kehidupan tidak hanya merubah apa yang di 'permukaan' (kulit), tetapi juga merasuk hingga ke level 'substansi' (kesadaran dan ideologi).

Menarik disimak puisi kritis yang ditulis Ariel Heryanto (November 1993) berjudul "Dewi Syuga: Kok Pintar, Kok Cantik, Kok Bebas", penggalannya misalnya:

“...Di negeri kami tubuh perempuan bukan milik perempuan

Dada dan paha sudah dijatahkan

buat biro iklan dan wartawan

Vagina dan rahim adalah lahan resmi proyek nasional KB...

dikerjakan sehari-hari dalam keluarga oleh laki-laki kami sendiri dilaporkan birokrat negeri biar dapat utang luar negeri..."

\section{Penutup}

\section{A. Kesimpulan}

Sistem ideologi mempunyai hubungan langsung dengan pengalaman manusia hidup di dalam masyarakat secara total. Ideologi itu tidak saja melingkupi bidang pengetahuan dan gagasan saja, tetapi 
juga meluas pada simbol, mitos, selera, gaya, fashion, iklan, televisi, media massa, interior rumah, mobil, dan seluruh 'cara hidup' suatu masyarakat. Dalam konteks industri kreatif, simbol keagamaan telah "diperjualbelikan" sebagai komoditi, sebab kesadaran supra-struktur dikendalikan oleh dominasi struktur. Realitas wacana seni keagamaan telah kehilangan dimensi 'sakralnya', sebuah informasi telah kehilangan dimensi 'maknanya', sebuah karya seni telah kehilangan dimensi 'auranya'. Wacana seni keagamaan menjauhkan diri dari dialektika 'makna' (ideologis), juga dialektika komunikasi dan sosialisasi. Dialektika ideologis dianggap membosankan. Wacana seni telah tercebur ke dalam ideologi tanpa batas dengan cara menghancurkan esensi makna itu sendiri, menggali sisi ekstrimnya, mengekspos dimensi ekstasi, kecabulan, dan immmoralitasnya. Estetika kontemporer tidak lagi membedakan mana yang 'indah', mana yang 'jelek', mana yang 'moral, mana yang 'amoral'. Akibatnya, kehadiran konsumerisme, hedonisme, dan pleasure dalam suatu media akan selalu menjadi ancaman terhadap dasar-dasar keimanan, norma, nilai agama, tradisi, etika, estetika, dan bahkan konstitusi yang berlaku.

Jika dicermati, regulasi siaran atau tayangan televisi yang diwakili oleh lembaga KPI, cukup memiliki visi dan misi yang jauh ke depan, terutama bagi penguatan nilai-nilai moral dalam masyarakat dan menjamin pluralisme pada masyarakat Indonesia, yang pada gilirannya akan mendukung transformasi sosial pada perubahan sikap, nilai, dan kesadaran kritis warga negara. Artinya, suatu tayangan televisi harus mampu memenuhi persyaratan, yang terpenting antara lain (1) legitimasi sosiologis atau penerimaan masyarakat; (2) legitimasi legalitas atau kesesuain dengan hukum yang disepakati dan berlaku; (3) legitimasi etis atau diterima berdasarkan standar moral masyarakatnya.

\section{B. SARAN/ReKomendasi}

Untuk mewujudkan fungsi media televisi sebagai wadah pencerahan, edukasi, informasi, sekaligus sebagai refreshing bagi masyarakat, maka negara harus memainkan peran penting dalam "mendamaikan" seluruh kepentingan. Sebagai fungsi regulator, negara-dalam hal ini KPI-harus dipercaya dan diberi kewewenangan mengatur kebijakan media sehingga dapat menghasilkan keputusan yang bersifat win win solution. Jadi, eksistensi kelembagaan KPI sebagai "pengayom" perlu diperkuat sehingga kebijakan yang dihasilkannya dapat dihormati oleh seluruh pihak, tetapi tetap berada dalam koridor hukum dan kultur masyarakat Indonesia yang beragam baik secara etnis, agama, dan budaya.[] 
Alex Sobur. 2001. Analisis Teks Media: Suatu Pengantar untuk Analisis Wacana, Analisis Semiotik, dan Analisis Framing. PT Remaja Rosdakarya, Bandung

Andrik Puwasito. "Analisis Semiologi Komunikasi sebagai Tafsir Pesan". Jurnal Komunikasi Massa, Vol. 1, No. 1, Januari 2008

Ashadi Siregas dkk. 2000. Eksplorasi Gender dalam Ranah Jurnalisme dan Hiburan. LP3Y dan Ford Foundation, Yogyakarta

Burhan Bungin. 2003. Pornomedia: Konstruksi Sosial Telematika $\mathcal{E}$ Perayaan Seks di Media Massa. Kencana, Bogor.

Camille Paglia. 1992. Sex, Art and American Culture. Viking, London \& New York

Deddi Duto Hartanto. 2007. “Analisa Tayangan Kerajaan Sahur Trans TV sebagai Representasi Mass Culture", dalam Jurnal NIRMANA, VOL.9, NO. 1, Januari 2007: 1-9

Eriyanto. 2002. Analisis Framing: Konstruksi, Ideologi, dan Politik Media. LKis, Yogyakarta

- - - . 2001. Analisis Wacana: Pengantar Analisis Teks Media. LKis, Yogyakarta

Fachrizal A. Halim. 2002. Beragama dalam Belenggu Kapitalisme.
Indonesiatera, Magelang

Irwan Abdullah. 1997. Sangkaan paran gender. Yogyakarta: Pustaka Pelajar

John Storey. 2003. Teori Budaya dan Budaya Pop: Memetakan Lanskap Konseptual Cultural Studies. CV. Qalam, Yogyakarta

Juwono Tri Atmodjo. t.t. Analisis Isi (Content Analysis). Dalam Modul Riset $P R$ Fikom Universitas Mercubuana Jakarta

Klaus Krippendorff. 1993. Analisis Isi: Pengantar Teori dan Metodologi. RajaGrafindo Persada, Jakarta

Muhammad Arkoun. 1994. Metode kritik akal Islam. Ulumul Qur'an. Vol. V, No. 5 \& 6, h. 156-169

Norman Fairclough. 1995. Media discourse. London: Edward Arnold

Santi Indra Astuti. 2005. "Ramadan dalam Bingkai Religius di Televisi: Kajian atas Kognisi Sosial, Mode Produksi, dan Fenomena Infotainment dalam Program Sahur". Tesis UI, Jakarta

Tri Hastuti Nur R. 2003. “Stereotipe dan Komoditisasi Perempuan dalam Iklan". Dalam Jurnal Perempuan: untuk Pencerahan dan Kesetaraan No.28. Yayasan Jurnal Perempuan, Jakarta 